\title{
ASSESMENT AND UTILIZATION OF SELECTION INDICES IN IMPROVEMENT OF MUNGBEAN
}

\author{
V. S. Girase, M. A. Barate, V. V. Bhavsar and K. K. Barhate \\ Botany Section, College of Agriculture, Dhule-424 004 (MS), INDIA
}

\author{
Communicated : 14.02 .20
}

Revision :07.03.20 \& 10.4.2020

Accepted : 21.05.2020

Published: 30.05 .2020

\begin{abstract}
:
The seed yield per plant showed highly significant and positive association with pod length (0.486), followed by 100 seed weight (0.463), number of seeds per pod (0.354), number of pods per plant $(0.310)$, number of clusters per plant $(0.276)$, plant height $(0.256)$, number of primary branches per plant $(0.226)$ whereas seed shattering $(0.011)$ showed positive and non-significant association with seed yield at the genotypic level. The character days to maturity (0.378) showed negative and significant association with seed yield per plant. The characters 50 per cent flowering (-0.125), number of pods per cluster (-0.121) and protein content (-0.025) showed negative and non-significant association with seed yield.
\end{abstract}

Key words:- Genotypic and Phenotypic Correlation, Selection Indices, Mungbean

\section{INTRODUCTION:}

Mungbean, (Vigna radiata (L.) Wilczek), commonly known as green gram, is one of the important among thirteen different seed legumes grown in India. Among pulses, mungbean holds an important position, as it contains more digestible proteins and also provides calories in Asian diets. Mungbean is consumed in variety of ways. Sprouted mungbean are used as fresh vegetable in Chinese and Japanese diet and also used in South India for curry preparation or savoury dish. Proteins isolated from it have been used for making noodles and other textured preparations [Bhumiratnam,1978]. Correlation analysis has been widely used to determine the nature and magnitude of inter-relationships between grain yield and its contributing components. The correlation analysis measures mutual relationship between various characters and it determines the component traits on which selection can be relied upon to affect the improvement. Yield being a complex character is influenced by a number of yields contributing characters controlling by polygene and also influenced by environment. Hence, it becomes necessary to partition the genotypic and phenotypic correlation.

\section{MATERIALS AND METHODS:}

A piece of land selected for experiment was brought to fine tilt by ploughing followed by harrowing. The 60 genotypes of mungbean were evaluated in a RBD with two replications. Sowing of experiment was done on 13th-June 2018 at spacing of $30 \times 10 \mathrm{~cm}$.

\section{Correlation co-efficient}

The simple correlation coefficients were calculated to determine the degree of association of different characters with grain yield and also among yield components. The estimated correlation coefficients were compared against Table ' $r$ ' values at (n-2) d.f. at the probability levels of 0.05 and 0.01 to test their significance. Simple correlations were computed by using the formula as given below. 


$$
r=\frac{\text { Cov. } \mathrm{xy}}{\mathrm{Vx} \cdot \mathrm{Vy}}
$$

Where, Cov.xy = Covariance between the characters $\mathrm{x}$ and $\mathrm{y} \quad \mathrm{Vx}=$ Variance of the character $\mathrm{x}$,

$$
\mathrm{Vy}=\text { Variance of the character }
$$

\section{RESULTS AND DISCUSSION}

\section{Correlation co-efficient}

The table 1and 2 represents the correlation co-efficient between the characters at genotypic as well as phenotypic levels. As the genetic correlation is important from breeding point of view, those only are described below. In an improvement of any crop, yield is the most important character that has to be taken in to consideration. The knowledge of inter relationship among the characters, especially with yield is therefore useful to the plant breeder for improving efficiency of selection. The degree of correlation observable among attributes will depend on the development of relations between them and on genes which contribute to the variation. The phenotypic correlation indicates the extent of the observed relationships between two characters. This does not give a true genetic picture of relationship, because it indicates the effects of both heredity as well as environment. The genotypic correlations provide an estimate of an inherent association between genes controlling two characters. The estimates of correlation coefficients may also help to identify the characters that prove to be of little or no importance in the selection program. In the present studies, the genotypic correlations were nearly equal to the phenotypic correlations. This indicates that there was a strong inherent association between them and the genotypic expression of correlation was less influenced by environmental factors. This result confirms the earlier findings of Hakim et al. [2008].

\section{A. Genotypic correlations co-efficients:}

Days to 50 per cent flowering was showed highly significant and positive correlation

with days to maturity (0.309), followed by seed shattering (0.301) and positive and nonsignificant correlation with number of primary branches per plant (0.167), number of seeds per pod (0.053). It also showed non-significant and negative correlation with number of pods per plant (-0.141), number of pods per cluster (0.130), seed yield (-0.125), 100 seed weight (0.106), plant height (-0.079), pod length ($0.064)$ and number of clusters per plant (0.002).

Days to $50 \%$ flowering had nonsignificant positive correlation with grain yield per plant at genotypic level, indicated that early flowering genotypes are desirable for grain yield per plant( Table 1). These results confirm the earlier finding of Hakim (2008). The days to 50 $\%$ flowering was positively and significantly correlated with days to maturity, indicated the direct relationship between them and improvement in both the traits as well as yield could be achieved by exercising selection for either of the trait. A similar result was also reported by Dangi et al. [2017].

Days to maturity was showed significant and positive correlation with days to 50 per cent flowering (0.309), number of primary branches per plant (0.290). It showed positive but, non-significant correlation with number of pods per plant (0.107), number of pods per cluster (0.020), number of seeds per pod (0.0245) and seed shattering (0.023). Seed yield per plant (-0.378), pod length (-0.329) and 100 seed weight (-0.326) was significantly and negatively correlated with days to maturity. Days to maturity had significant but negative correlation with grain yield per plant at genotypic level, indicated that early flowering and short duration genotypes are desirable for 
I J R B A T, Issue (VIII), Vol. II, May 2020: 59-67

A Double Blind Peer Reviewed Journal
e-ISSN $2347-517 X$

Original Article grain yield per plant; these results confirm the earlier finding of Hakim [2008] and Dangi et al. [2017].

Plant height showed strong positive and significant correlation with protein content (0.447) followed by pod length (0.360) and seed yield per plant (0.256). Plant height showed positive but non-significant correlation with number of pods per cluster (0.121), seed shattering (0.082), number of seeds per pod (0.058) and 100 seed weight (0.010). It showed highly negative and significant correlation with number of clusters per plant (-0.348).

Plant height had significant positive correlation with grain yield per plant, indicated that, the tall to medium stature genotypes are desirable for more grain yield per plant. These results are in conformity with results of Srivastava and Singh [2012] and Garg et al. [2017].

Number of primary branches per plant exhibited strong positive and significant correlation with number of clusters per plant (0.667), number of pods per plant (0.514) days to maturity (0.290), seed yield per plant (0.226). Whereas it showed positive but non-significant correlation with number of seeds per pod (0.168), days to 50 per cent flowering (0.167), 100seed weight (0.017) and seed shattering (0.045). It had negative and significant correlation with protein content (-0.288), number of pods per cluster (-0.273). It also showed negative and non-significant correlation with plant height (-0.139), and pod length (0.119).

The genotypes having more numbers of primary branches per plant could produce more number of clusters per plant and finally more grain yield per plant. These confirm the earlier finding of Singh et al. [2011] and Dangi et al. [2017].

Number of clusters per plant exhibited strong positive and significant correlation with number of primary branches per plant (0.667), number of pods per plant (0.385) and seed yield per plant (0.276), indicated the proportional relationship between them. Whereas it showed positive but non-significant correlation with seed shattering (0.145) and 100-seed weight (0.126). It had negative and significant correlation with number of pods per cluster (0.752), plant height $(-0.348)$ and protein content $(-0.188)$. It exhibited negative but nonsignificant correlation with days to maturity (0.069), pod length (-0.059), number of seeds per pod (-0.051) and days to 50 per cent flowering (0.002). Similar results were reported by Kumar et al. [2013] and Dangi et al. [2017].

Number of pods per cluster showed significant and positive correlation with number of pods per plant (0.222), whereas it showed positive but non-significant correlation with protein content $(0.159)$, plant height $(0.121)$ and days to maturity (0.055). It also showed negative and significant correlation with number of cluster per plant (-0.752), 100 seed weight (-0.306), number of primary branches per plant (-0.273) and pod length (-0.273). Similar report was also made by Eswaran et al. [2015].

Number of pods per plant showed highly significant and the highest positive correlation with number of primary branches per plant (0.514), number of clusters per plant (0.385), seed yield per plant (0.310) and number of pods per cluster (0.222). It also showed positive but non-significant correlation with seed shattering (0.116) and days to maturity (0.107). It also showed negative and significant correlation with pod length (-0.473), 100 seed weight (-0.410) and number of seeds per pod (0.219). These results are in conformity with results of Thanga et al. [2015].

Number of pods per plant showed highly significant and positive correlation with 
grain yield per plant at genotypic level which were also reported by Thanga et al. [2015].

The character, number of seeds per pod had positive and significant correlation with pod length (0.811), 100-seed weight (0.754), seed yield per plant (0.354) and protein content (0.329). The number of seeds per pod showed positive but non-significant correlation with number of primary branches per plant (0.168), seed shattering (0.107), plant height (0.058), days to 50 per cent flowering (0.053) and days to maturity (0.024). It also showed negative and significant correlation with number of pods per plant (-0.219), whereas it exhibited negative non-significant correlation with number of pods per cluster (-0.107) and number of clusters per plant (-0.051).

Number of seeds per pod had the significant and positive correlation with pod length, 100 seed weight and grain yield per plant. This is the acute desirable situation in mungbean for obtaining bold seeded, long podded and high yielding genotype for which farmers has been eagerly waiting. Similar observations were also reported by Eswaran et al. [2015].

The pod length had highly significant and positive correlation with number of seeds per pod (0.811) and 100 seed weight (0.733), indicated that, the long pod genotypes could produce more number of seeds per pod and more 100-seeds weight. It showed negative and significant correlation with number of pods per plant (-0.473), days to maturity $(-0.329)$ and number of pods per cluster (0.273). These results are corroborated with the results of Singh et al., [2011] and Eswaran et al. [2015].

The 100-seed weight had highly significant and positive correlation with pod length (0.773), number of seeds per pod (0.754) and seed yield per plant (0.463). It showed negative and significant correlation with number of pods per plant (-0.410) and number of pods per cluster (-0.306). These results are corroborated with the results of Eswaran et al. [2015].

The association of protein content with plant height (0.447), number of seeds per pod (0.329) and pod length (0.286) was positive and significant. Protein content showed negative and significant correlation with days to 50 per cent flowering (-0.345), number of primary branches per plant $(-0.288)$ and positive but, non-significant correlation with 100 seed weight $(0.160)$ and number of pods per cluster (0.159).

Seed shattering exhibited strong positive and significant correlation with days to 50 per cent flowering (0.301). It also showed negative but non-significant correlation with protein content (0.098), pod length (-0.007) and number of pods per cluster (-0.006). Similar observation was also made by Khedakar and Girase [2018] in soybean.

\section{B. Phenotypic correlation co-efficients:}

Days to 50 per cent flowering showed significant and positive correlation with seed shattering $(0.238)$ followed by days to maturity (0.224). It also showed positive but nonsignificant correlation with number of seeds per pod (0.078), plant height (0.072) and number of clusters per plant (0.050). It showed negative and significant correlation with protein content (0.205). It also showed negative but nonsignificant correlation with number of pods per plant (0.081), number of pods per cluster (0.080), 100-seed weight (-0.073), seed yield (0.072), pod length (-0.072) and number of primary branches per plant (-0.058).

Days to $50 \%$ flowering had nonsignificant negative correlation with grain yield per plant at genotypic level, indicated that early flowering genotypes are desirable for grain yield per plant (Table-2). These results confirm the earlier finding of Singh et al. [2011] 
Days to maturity exhibited highly significant and positive correlation with days to 50 per cent flowering (0.224). It reflected positive but non-significant correlation with number of primary branches per plant (0.122), number of seeds per pod (0.018), seed shattering (0.009), and number of pods per cluster (0.002). Days to maturity was significantly and negatively correlated with pod length (-0.252), 100-seed weight (-0.242) and seed yield per plant. Days to maturity had significant but negative correlation with grain yield per plant at genotypic level, indicated that early flowering and short duration genotypes are desirable for more grain yield per plant. These results confirm the earlier finding of Singh et al. [2011].

Plant height exhibited strong positive and significant correlation with pod length (0.256) followed by number of pods per cluster (0.220) and seed yield per plant (0.206). It showed negative and significant correlation with number of primary branches per plant (-0.258) and number of clusters per plant (-0.225). Plant height was positively correlated with the grain yield per plant was also reported by Dangi et al. [2017].

Number of primary branches per plant showed the highest positive and significant correlation with number of clusters per plant (0.545), number of pods per plant (0.353) and seed yield per plant (0.243). Number of primary branches per plant showed the positive and significant correlation with seed yield per plant. Indicated that, genotypes having more numbers of primary branches per plant could produce more number of clusters per plant and finally more grain yield per plant. This confirm the earlier finding of Singh et al. [2011] and Dangi et al. [2017].

Number of clusters per plant showed the highest positive and significant correlation with number of primary branches per plant (0.545) followed by number of pods per plant (0.318) and seed yield per plant (0.276). It showed negative and significant correlation with number of pods per cluster (-0.548) and plant height (-0.225). Number of clusters per plant showed the highest positive and significant correlation with seed yield per plant, which was also reported by Dangi et al. [2017].

Number of pods per cluster showed the highest positive and significant correlation with number of pods per plant (0.408) followed by plant height (0.220). It showed negative and significant correlation with number of clusters per plant (-0.548), 100 seed weight $(-0.227)$ and pod length (-0.204).

Number of pods per plant showed the highest positive and significant correlation with number of pods per cluster $(0.408)$ followed by seed yield per plant $(0.370)$, number of primary branches per plant (0.353) and number of clusters per plant (0.318). It showed negative and significant correlation with pod length ($0.343)$ and 100 seed weight (-0.295). Number of pods per plant showed the positive and significant correlation with seed yield per plant. These results are corroborated with the results of Garg et al. [2017].

The number of seeds per pod had positive and significant correlation with pod length (0.512), 100 seed weight (0.491) and seed yield per plant (0.228). The number of seeds per pod had positive but non-significant correlation with number of primary branches per plant (0.029) and protein content (0.044).The number of seeds per pod had positive and significant correlation with seed yield per plant, which were also reported by Dangi et al. [2017].

The pod length had highly positive and significant correlation with 100 seed weight (0.734), number of seeds per pod (0.512) and 
I J R B A T, Issue (VIII), Vol. II, May 2020: 59-67

A Double Blind Peer Reviewed Journal
e-ISSN $2347-517 X$

Original Article seed yield per plant (0.356). It showed negative and significant correlation with number of pods per plant (-0.343), days to maturity (-0.252) and number of pods per cluster (-0.202). Pod length had positive and significant association with seed yield per plant. These results confirm the earlier finding of Eswaran et al. [2015].

The 100-seed weight had highly positive and significant correlation with pod length (0.734), number of seeds per pod (0.491) and seed yield per plant (0.339). It showed negative and significant correlation with number of pods per plant (-0.295) and days to maturity (-0.242). The 100-seed weight had highly positive and significant correlation with seed yield per plant which were also reported by Dangi et al. [2017]. The protein content had positive and significant association with pod length (0.220). It had negative and significant correlation with days to 50 per cent flowering $(-0.205)$.

Seed shattering revealed positive and significant correlation with days to 50 per cent flowering (0.238), While, negative but nonsignificant correlation with protein content (0.066) and number of pods per cluster (0.059).Similar observations was also made by Khedakar and Girase [2018] in soybean.

\section{CONCLUSION:}

In the present investigation, Seed yield per plant showed negative and significant correlation with days to maturity $(-0.378)$ at both the level. The association between number of pods per plant with 100 seed weight and pod length with number of seeds per pod was significant and positive, which is desirable situation for improvement of these traits in mungbean. Secondly, the seed yield per plant showed highly significant and positive association with pod length (0.486), followed by 100 seed weight (0.463), number of seeds per pod (0.354), number of pods per plant (0.310), number of clusters per plant (0.276), plant height $(0.256)$ and number of primary branches per plant (0.226) at genotypic level, indicated that, these are the important yield contributing traits and due weightage should be given to these traits during the selection for improvement of yield and its components for development of genotype sustainable for climate change.

\section{REFERENCES:}

Bhumiratnam A. 1978. Mungbean and its utilization in Thailand."Proc.First Intern.MungbeanSymp." AVRDC, Taiwan. 46-48.

Dangi R. K. Gurjar D., Singh P. B. and Lavanya G. R.2017. Correlation Studies on Morphological and Yield Characters of Mungbean [Vignaradiata(L.) Wilczek]. J. Multidisciplinary Advance Res., 6(1): 6-9

Eswaran R .and Senthilkumar N., 2015. Correlation and Path Analysis in Greengram [Vigna radiata (L.) Wilczek] For Drought Stress. Plant Archives, 15(1):247-249.

Garg G.K., Verma P.K. and Kesh H. 2017. Genetic Variability, Correlation and Path Analysis in Mungbean [Vigna radiate (L.)Wilczek].Int. J. Current Microbiol. App. Sci.,6(11): 2166- 2173

Hakim L. 2008. Variability and correlation of agronomic characters of Mungbean Germplasm and their utilization for varietal improvement program. Indonesian J. Agric. Sci., 9(1): 24-28.

Khedkar D.J. and Girase V. S. 2018. Evaluation of soybean germplasm for shattering resistance. Int. J. Chemical Studies, 6(4):2854-2858 .

Kumar, K., Prasad, Y., Mishra, S. B., Pandey, S. S. and Ravi, K. 2013.Study on genetic variability, correlation and path analysis with grain yield and yield attributing traits 
in green gram [VignaRadiata (L) Wilczek]. The Bioscan. 8(4): 1551-55.

Singh A. K., Lavanya G. R. and Paul. P. J. 2011. Genetic variability and character association in F2 generation of Mungbean[Vignaradiata(L.) Wilczek]. J. Agric. Res. Technol., 36 (2): 342-344.

Srivastava R. L. and Singh G. 2012. Genetic Variability, Correlation and Path Analysis in mungbean[Vignaradiata(L.) Wilczek] Indian J. L. Sci., 2(1): 61-65. 
Table 1. Genotypic correlation for thirteen characters in sixty genotypes of mungbean.

\begin{tabular}{|c|c|c|c|c|c|c|c|c|c|c|c|c|c|}
\hline Characters & $\begin{array}{c}\text { Days } \\
\text { to } \\
50 \% \\
\text { floweri } \\
\text { ng }\end{array}$ & $\begin{array}{c}\text { Days } \\
\text { To } \\
\text { Maturity }\end{array}$ & $\begin{array}{l}\text { Plant } \\
\text { heigh } \\
t(\mathbf{c m})\end{array}$ & $\begin{array}{c}\text { No. of } \\
\text { primary } \\
\text { branches } \\
\text { per plant }\end{array}$ & $\begin{array}{c}\text { No. of } \\
\text { clusters } \\
\text { per plant }\end{array}$ & $\begin{array}{l}\text { No. of } \\
\text { pods per } \\
\text { cluster }\end{array}$ & $\begin{array}{c}\text { No. } \\
\text { of pods } \\
\text { per } \\
\text { plant }\end{array}$ & $\begin{array}{c}\text { No. of } \\
\text { seeds } \\
\text { per pod }\end{array}$ & $\begin{array}{l}\text { Pod } \\
\text { length } \\
\text { (cm) }\end{array}$ & $\begin{array}{c}100 \\
\text { seed } \\
\text { weight } \\
\text { (g) }\end{array}$ & $\begin{array}{c}\text { Protein } \\
\text { content } \\
(\%)\end{array}$ & $\begin{array}{c}\text { Seed } \\
\text { shatt. } \\
(\%)\end{array}$ & $\begin{array}{l}\text { Seed } \\
\text { yield per } \\
\text { plant } \\
\text { (g) }\end{array}$ \\
\hline $\begin{array}{c}\text { Days to } 50 \% \\
\text { flowering }\end{array}$ & 1.000 & $0.309 * *$ & -0.079 & 0.167 & -0.001 & -0.130 & -0.141 & 0.053 & -0.064 & -0.106 & $-0.345^{* *}$ & $0.301^{* *}$ & -0.125 \\
\hline $\begin{array}{l}\text { Days to } \\
\text { maturity }\end{array}$ & & 1.000 & -0.135 & $0.290 * *$ & -0.069 & 0.055 & 0.107 & 0.024 & $-0.329 * *$ & $-0.326^{* *}$ & -0.139 & 0.023 & $-0.378^{* *}$ \\
\hline Plant height & & & 1.000 & -0.139 & $-0.348 * *$ & 0.121 & -0.073 & 0.058 & $0.360 * *$ & 0.010 & $0.447 * *$ & 0.082 & $0.256^{* *}$ \\
\hline $\begin{array}{c}\text { No. of primary } \\
\text { branches per } \\
\text { plant }\end{array}$ & & & & 1.000 & $0.667^{* *}$ & $-0.273^{* *}$ & $0.514 * *$ & 0.168 & -0.119 & 0.017 & $-0.288 * *$ & 0.045 & $0.226^{*}$ \\
\hline $\begin{array}{l}\text { No. of cluster } \\
\text { per plant }\end{array}$ & & & & & 1.000 & $-0.752^{* *}$ & $0.385^{* *}$ & -0.051 & -0.059 & 0.126 & -0.188 & 0.145 & $0.276^{* *}$ \\
\hline $\begin{array}{l}\text { No. of pods per } \\
\text { cluster }\end{array}$ & & & & & & 1.000 & $0.222^{*}$ & $-0.219 *$ & $-0.473^{* *}$ & $-0.410^{* *}$ & -0.048 & 0.116 & -0.121 \\
\hline $\begin{array}{l}\text { No. of pods per } \\
\text { plant }\end{array}$ & & & & & & & 1.000 & -0.107 & $-0.273^{* *}$ & $-0.306^{* *}$ & 0.159 & -0.065 & $0.310^{* *}$ \\
\hline $\begin{array}{c}\text { No. of seeds } \\
\text { per pod }\end{array}$ & & & & & & & & 1.000 & $0.811^{* *}$ & $0.754^{* *}$ & $0.329 * *$ & 0.107 & $0.354^{* *}$ \\
\hline Pod length & & & & & & & & & 1.000 & $0.773^{* *}$ & $0.286^{* *}$ & -0.007 & $0.486^{* *}$ \\
\hline $\begin{array}{c}100 \text { seed } \\
\text { weight }\end{array}$ & & & & & & & & & & 1.000 & 0.160 & 0.072 & $0.463^{* *}$ \\
\hline $\begin{array}{l}\text { Protein } \\
\text { content }\end{array}$ & & & & & & & & & & & 1.000 & -0.098 & -0.025 \\
\hline $\begin{array}{c}\text { Seed } \\
\text { shattering }\end{array}$ & & & & & & & & & & & & 1.000 & 0.011 \\
\hline $\begin{array}{c}\text { Seed yield per } \\
\text { plant }\end{array}$ & & & & & & & & & & & & & 1.000 \\
\hline
\end{tabular}

${ }^{*}=$ Significant at $5 \%$ level, ${ }^{* *}=$ Significant at $1 \%$ level 
Table 2. Phenotypic correlation for thirteen characters in sixty genotypes of mungbean

\begin{tabular}{|c|c|c|c|c|c|c|c|c|c|c|c|c|c|}
\hline Characters & $\begin{array}{c}\text { Days } \\
\text { to } \\
50 \% \\
\text { flower } \\
\text { ing }\end{array}$ & $\begin{array}{c}\text { Days } \\
\text { To } \\
\text { Maturit } \\
\mathbf{y}\end{array}$ & $\begin{array}{l}\text { Plant } \\
\text { height } \\
\text { (cm) }\end{array}$ & $\begin{array}{c}\text { No. of } \\
\text { primary } \\
\text { branche } \\
\text { s per } \\
\text { plant }\end{array}$ & $\begin{array}{l}\text { No. of } \\
\text { clusters } \\
\text { per plant }\end{array}$ & $\begin{array}{l}\text { No. of } \\
\text { pods per } \\
\text { cluster }\end{array}$ & $\begin{array}{c}\text { No. } \\
\text { of pods } \\
\text { per plant }\end{array}$ & $\begin{array}{l}\text { No. of } \\
\text { seeds } \\
\text { per pod }\end{array}$ & $\begin{array}{l}\text { Pod } \\
\text { length } \\
\text { (cm) }\end{array}$ & $\begin{array}{c}100 \\
\text { seed } \\
\text { weight } \\
\text { (g) }\end{array}$ & $\begin{array}{l}\text { Protein } \\
\text { content } \\
\text { (\%) }\end{array}$ & $\begin{array}{c}\text { Seed } \\
\text { shatt. } \\
(\%)\end{array}$ & $\begin{array}{c}\text { Seed } \\
\text { yield per } \\
\text { plant } \\
\text { (g) }\end{array}$ \\
\hline $\begin{array}{c}\text { Days to } \mathbf{5 0} \% \\
\text { flowering }\end{array}$ & 1.000 & $0.224^{*}$ & 0.072 & -0.058 & 0.050 & -0.080 & -0.081 & 0.078 & -0.072 & -0.073 & $-0.205^{*}$ & $0.238^{* *}$ & -0.072 \\
\hline $\begin{array}{c}\text { Days to } \\
\text { maturity }\end{array}$ & & 1.000 & -0.054 & 0.122 & -0.093 & 0.002 & -0.017 & 0.018 & $-0.252^{* *}$ & $-0.242^{* *}$ & -0.030 & 0.008 & $-0.213^{*}$ \\
\hline Plant height & & & 1.000 & $-0.258^{* *}$ & $-0.225^{*}$ & $0.220^{*}$ & -0.009 & -0.013 & $0.256^{* *}$ & 0.030 & 0.072 & 0.052 & $0.206^{*}$ \\
\hline $\begin{array}{c}\text { No. of primary } \\
\text { branches per } \\
\text { plant }\end{array}$ & & & & 1.000 & $0.545^{* *}$ & $-0.185^{*}$ & $0.353^{* *}$ & 0.146 & -0.058 & 0.010 & -0.087 & 0.007 & $0.243^{\text {** }}$ \\
\hline $\begin{array}{l}\text { No. of cluster } \\
\text { per plant }\end{array}$ & & & & & 1.000 & $-0.548^{* *}$ & $0.318^{* *}$ & -0.005 & -0.019 & 0.105 & -0.124 & 0.122 & $0.276^{\text {** }}$ \\
\hline $\begin{array}{l}\text { No. of pods } \\
\text { per cluster }\end{array}$ & & & & & & 1.000 & $0.408^{* *}$ & -0.176 & $-0.343^{* *}$ & $-0.295^{* *}$ & -0.001 & 0.071 & $0.370^{* *}$ \\
\hline $\begin{array}{l}\text { No. of pods } \\
\text { per plant }\end{array}$ & & & & & & & 1.000 & -0.048 & $-0.202^{*}$ & $-0.227^{*}$ & 0.038 & -0.059 & 0.088 \\
\hline $\begin{array}{l}\text { No. of seeds } \\
\text { per pod }\end{array}$ & & & & & & & & 1.000 & $0.512^{* *}$ & $0.491^{* *}$ & 0.127 & 0.077 & $0.228^{*}$ \\
\hline Pod length & & & & & & & & & 1.000 & $0.734^{* *}$ & $0.220^{*}$ & -0.005 & $0.356^{* *}$ \\
\hline $\begin{array}{c}100 \text { seed } \\
\text { weight }\end{array}$ & & & & & & & & & & 1.000 & 0.118 & 0.069 & $0.339^{* *}$ \\
\hline $\begin{array}{l}\text { Protein } \\
\text { content }\end{array}$ & & & & & & & & & & & 1.000 & -0.066 & 0.006 \\
\hline $\begin{array}{c}\text { Seed } \\
\text { shattering }\end{array}$ & & & & & & & & & & & & 1.000 & -0.010 \\
\hline $\begin{array}{l}\text { Seed yield per } \\
\text { plant }\end{array}$ & & & & & & & & & & & & & 1.0000 \\
\hline
\end{tabular}

